\title{
Detection of Smoldering Fire Using Tin Oxide Gas Sensors
}

\author{
Tsubasa Higashino Student Member (Kanazawa Seiryo University) \\ Ayako Sawada Member (Kanazawa Seiryo University) \\ Takashi Oyabu Member (Kanazawa Seiryo University) \\ Yoshinori Takei Member (Kanazawa Institute of Technology) \\ Hidehito Nanto Member (Kanazawa Institute of Technology) \\ Kiyoshi Toko Member (Kyushu University)
}

Keywords : gas sensor, smoldering fire, principle component analysis, differential characteristic, sensory system

Detecting technique of smoldering fire was examined using tin oxide gas sensors. Eight sensors were installed in a room. They were same type. Four kinds of materials were adopted as a fire-source material. The materials were cotton cloth, wallpaper, curtain cloth and woodchip, which were main smoldering fire-source materials in an indoor environment. The sensor outputs to gases evolved upon the smoldering fire of the materials were measured. The differential characteristic of the output was derived to analyze. As for the results, it became obvious that the sensor locating at higher position had a higher sensitivity and it could sense the fire instantaneously. It is thought that the generated gases rise up directly toward the ceiling and reflect downward. A small type of electric cooking stove was used as a fire-source. The surface temperature of the stove plate arrived at $340{ }^{\circ} \mathrm{C}$. A bar was adopted to set the sensors freely. In this experiment, three bars were adopted and the heights of the sensor position were 50, 100, 150 and $200 \mathrm{~cm}$ from the floor. It is effective to locate the sensor at higher position in detecting a smoldering fire. The sensor characteristics were analyzed using principal component analysis (PCA). The system could discriminate source materials among wallpaper, woodchip and curtain for smoldering fire by utilizing the result of PCA. But, the smoldering fire of cotton cloth could not be distinguished from that of curtain by this system. Each fire could be identified in four minutes.

Typical sensor characteristics for smoldering fire of cotton cloth are shown in Fig. 1. The ch 5 sensor has a higher output. The sensor is located at the highest position of center bar. The outputs

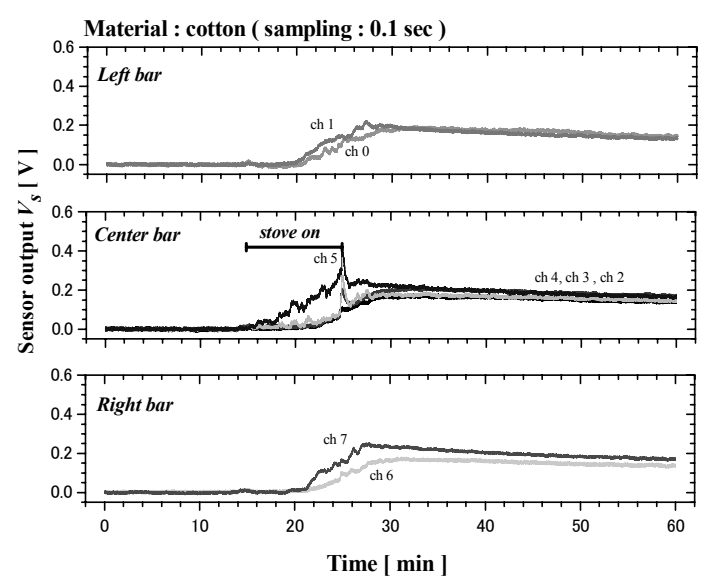

Fig. 1. Sensor characteristics for smoldering fire of cotton cloth were measured every $0.1 \mathrm{~ms}$ and they were summed for two seconds. It is called as integreted value.The differential characteristics for the integreted values are shown in Fig. 2.The characteristics ch 4 and 5 change largely. These sensors are near the fire-source. The threshold value $\left(V_{t h}\right)$ was introduced for the characteristics and the time in which the characteristics exceeded the $V_{t h}$ was derived. PCA was applied to the time.The result is indecated in Fig. 3. It is effective to discriminate three materials as a fire material. It is also effective to be located the sensor at higher position.

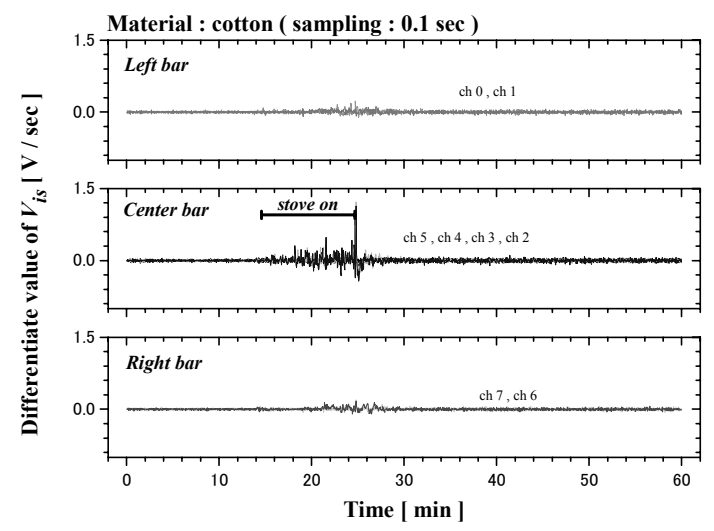

Fig. 2. Differential characteristics of integrated value for smoldering fire of cotton cloth

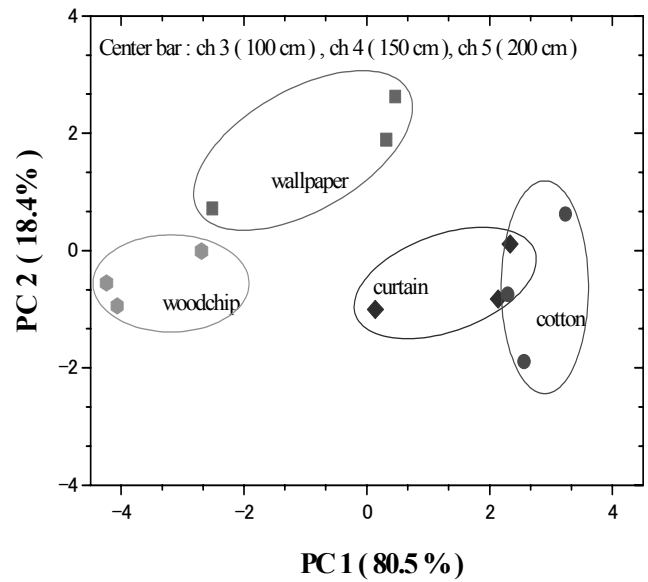

Fig. 3. Principal component analysis results of ch 3,4 and 5 sensors for four types of smoldering fire 


\section{ガスセンサによる燻焼火災検知}

$\begin{array}{llllll}\text { 学生員 東野 翼* } & \text { 正 員 } & \text { 沢田 } & \text { 史子* } \\ \text { 正員 大粉多可志* } & \text { 正 員 竹井 } & \text { 義法** } \\ \text { 正員 南戸 } & \text { 秀仁** } & \text { 正 員 都甲 } & \text { 潔*** }\end{array}$

\section{Detection of Smoldering Fire Using Tin Oxide Gas Sensors}

Tsubasa Higashino*, Student Member, Ayako Sawada*, Member, Takashi Oyabu*, Member

Yoshinori Takei**, Member, Hidehito Nanto**, Member, Kiyoshi Toko***, Member

Detecting technique of smoldering fire was examined using tin oxide gas sensors. Eight sensors were installed in a room. They were same type. Four kinds of materials were adopted as a fire-source material. The materials were cotton cloth, wallpaper, curtain cloth and woodchip, which were main smoldering fire-source materials in an indoor environment. The sensor outputs to gases evolved upon the smoldering fire of the materials were measured. The differential characteristic of the output was derived to analyze. As for the results, it became obvious that the sensor locating at higher position had a higher sensitivity and it could sense the fire instantaneously. It is thought that the generated gases rise up directly toward the ceiling and reflect downward. A small type of electric cooking stove was used as a fire-source. The surface temperature of the stove plate arrived at $340{ }^{\circ} \mathrm{C}$. A bar was adopted to set the sensors freely. In this experiment, three bars were adopted and the heights of the sensor position were 50 , 100,150 and $200 \mathrm{~cm}$ from the floor. It is effective to locate the sensor at higher position in detecting a smoldering fire. The sensor characteristics were analyzed using principal component analysis (PCA). The system could discriminate source materials among wallpaper, woodchip and curtain for smoldering fire by utilizing the result of PCA. But, the smoldering fire of cotton cloth could not be distinguished from that of curtain by this system. Each fire could be identified in four minutes.

キーワード：ガスセンサ，燻焼火災，主成分分析，差分特性，センサシステム

Keywords : gas sensor, smoldering fire, principal component analysis, differential characteristic, sensory system

\section{1. はじめに}

日本における火災件数は年々増加傾向にある。2004 年度 における住宅火災死者数は 1038 人(放火自殺者を除く)に達 し, その内 590 人(約 $60 \%)$ が 65 歳以上の高齢者である ${ }^{(1)}$ 。 高齢者は感覚の衰えから火災発生に気づくのが遅く大惨事 になるケースが多い。平成 18 年 6 月より新築住宅の寝室な どに火災警報器の設置が義務付けられた。既存住宅におい ても各市町村が定めた期日まで設置することが条例で定め

\section{* 金沢星稜大学}

T920-8620 石川県金沢市御所町丑 10 番地 1

Kanazawa Seiryo University

10-1Ushi, gosho, kanazawa-shi, ishikawa 920-8620

** 金沢工業大学・工学研究科

厂924-0838 石川県白山市八束穂 3 丁目 1 番地

Kanazawa Institute of Technology

3-1 Yatsukaho, Hakusan, Ishikawa 924-0838

*** 九州大学・システム情報化学研究院

T819-0395 福岡市西区元岡 744

Kyushu University

744 Moto-oka, Nishi-ku, Fukuoka 819-0395
られつつある。火災警報器を用いると比較的初期段階で覚 知できスピーディな消化が可能となる。火災警報器を用い ることにより死者発生割合は 3 分の 1 にとどまっている。 このため, 高感度センサ等を用いて, さらに火災を早期に 検知し発生位置, 火災源種の同定可能なシステム構築が必 要である。

6 種類 (建物, 林野, 車両, 船舶, 航空機, その他) の火 災の中で $55.2 \%$ が建物火災であり, その死者数の 8 割以上が 住宅火災 (一般, 共同, 併用住宅) で占められている。本研 究では，ガスセンサを用いて一般住宅における燻焼火災を 想定し早期検知システム構築を試みた。実験では 8 個の同 型酸化スズ系ガスセンサの応答特性を用いた。それらの特 性から火災源の位置と種類, 煙, 二オイの伝播スピードに ついて同定を試みた。火災源種として，木くず (woodchip), 壁紙 (wallpaper), カーテン布 (curtain), 綿布 (cotton)などを 採用した。これらは, 室内環境で火災源となる可能性の高 いものである。結果として, 高さの異なる位置のセンサ応 答特性に主成分分析法を適用することにより，火災源種を 
木くずと壁紙，カーテン布・綿布という 3 つのグループに 判別可能であった。ガスセンサ特性を用いることにより火 災源のみならず発生時刻, 位置を求めることも可能である。 当該センサを用いることにより，火災早期検知システムの 構築が可能であるとの知見を得た。

\section{2. 実験方法}

室内にセンサを取り付けるための 3 本の支柱を $70 \mathrm{~cm}$ 間隔 で配置し実験を行った。中央の支柱には，床より $50 \mathrm{~cm}$, $100 \mathrm{~cm}, 150 \mathrm{~cm}, 200 \mathrm{~cm}$ の位置にセンサを取り付けた。左右 の支柱には $100 \mathrm{~cm}, 150 \mathrm{~cm}$ の高さにセンサを取り付け，合計 8 個の酸化スズ系ガスセンサ（Figaro, TGS＃ 800）を取り付 けた。これらのセンサを ch 0 - 7 と称する。センサからの応 答は 0.1 秒間隔でコンピュータに取り込む。支柱に取り付け たセンサ番号を以下に示す。

- Left bar : ch 0 $(100 \mathrm{~cm}), \operatorname{ch} 1(150 \mathrm{~cm})$

- Center bar : ch $2(50 \mathrm{~cm})$, ch $3(100 \mathrm{~cm})$, ch $4(150 \mathrm{~cm}), \mathrm{ch}$ $5(200 \mathrm{~cm})$

- Right bar : ch $6(100 \mathrm{~cm}), \operatorname{ch} 7(150 \mathrm{~cm})$

実験室内の容積は $47.53 \mathrm{~m}^{3}$ である。その概要を Fig. 1 に示 す。(a)図はセンサや火災源のレイアウト，(b)図は実験装置 の構成である。実験では住宅内の燻焼火災を想定し，発火 源と考えられる物質をステンレス皿の上に置き，電気コン ロを使用し燻焼状態を導出した。ホテルや住宅で発生する 火災の多くがタバコ等による燻焼火災である。発火源に使 用した物質は木くず，カーテン布，綿布，壁紙である。各 試料の重さは $1 \mathrm{~g}$ とした，通電時間は 10 分間である。火災 源種は中央の支柱から $50 \mathrm{~cm}$ 離れた位置に配置した。実験は 各試料 3 回ずつ行った。各センサの出力 $V_{s}$ を計測し煙や二 オイの伝播特性を調べ火災源種の同定について検討した。

\section{3. 実験結果}

〈3・1〉 電気コンロの温度上昇特性 電気コンロに通 電したときのステンレス皿表面の温度上昇特性を Fig. 2 に 示す。通電後 10 分間で $340^{\circ} \mathrm{C}$ 到達する。この温度は, 雰 囲気温度や風量の有無により数 ${ }^{\circ} \mathrm{C}$ 差が生じる。このとき の風量と室内温度変化のグラフを Fig. 3 に示す。(a)図は, 室 内の風量変化特性である。最大で $0.07 \mathrm{~m} / \mathrm{sec}$ の風量が認めら

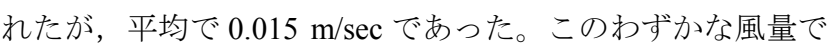
もセンサ特性に影響を与える。(b)図は，室内の温度変化特 性である。電気コンロの通電開始から約 2 分で室温が上昇 し, 10 分間の通電後電気コンロを $\mathrm{OFF}$ にしても 5 分間上昇 し続ける。すなわち, 通電開始から 15 分後に最大温度 $29^{\circ} \mathrm{C}$ に到達した。電気コンロを 10 分間作動させることにより約 $1{ }^{\circ} \mathrm{C}$ の室温上昇が認められた。

〈3·2〉燻焼火災によるセンサ特性 一般住宅の火災 要因として，衣類などが石油ストーブや電気ストーブに接 触し火災がおこるケースが考えられる。これを想定し，ス テンレス皿の上に綿布を置き燻焼実験を行った。その時の 出力結果を Fig. 4 に示す。Center bar の最も高い位置にある

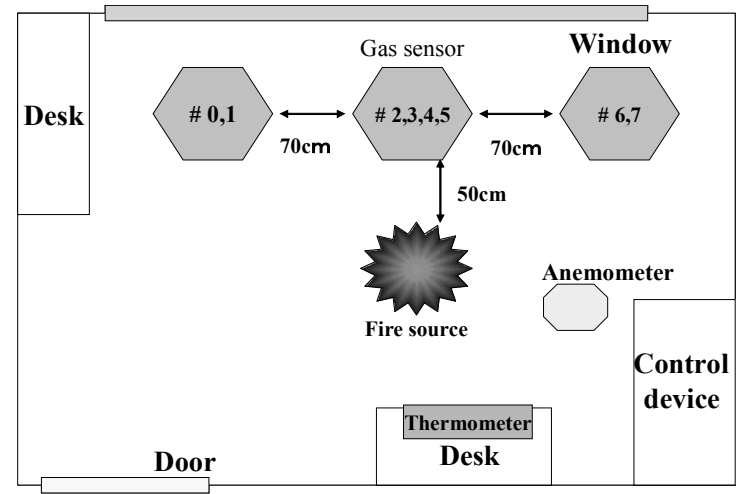

(a) 実験室のレイアウト

(a) Layout of experimental room.

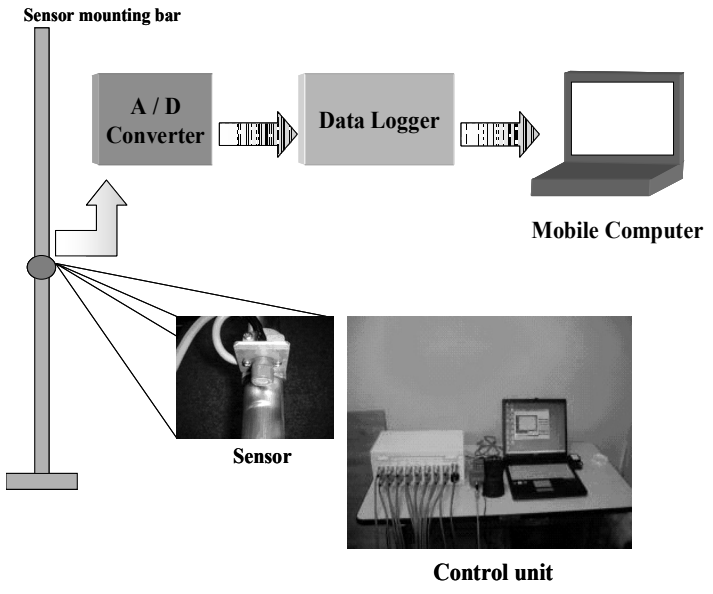

(b) 実験装置の構成

(b) Experimental system and gas sensor

図 1 実験室内のレイアウトと実験装置の構成

Fig. 1. Layout of experimental room and system.

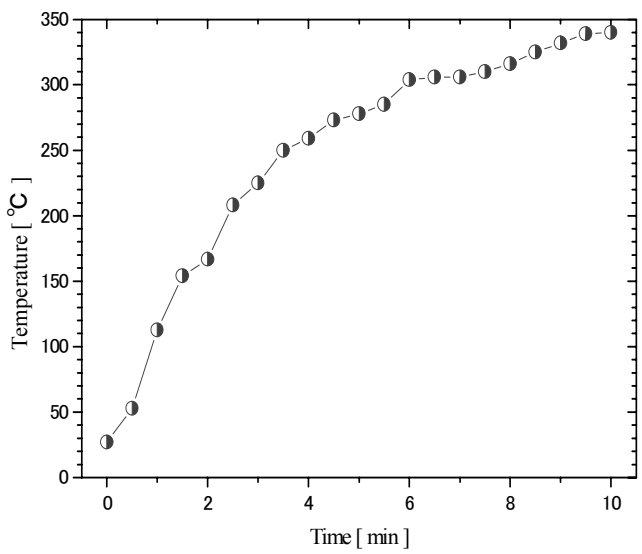

図 2 電気コンロ通電時のステンレス皿表面の温度変化

Fig. 2. Surface temperature of electric stove-plate.

センサ(ch5)の応答が高い。これは，燻焼火災により発生し たガス成分が，まず天井に到達し反射していると考えられ る。Fig. 4 の特性のノイズ成分を除去するためにセンサ出力 の 2 秒間毎の総和 (積分值) を求めた。その特性 $\left(V_{i s}\right)$ を Fig. 5 に示す。Fig. 4 の特徴を損なうことなくスムージングされて 


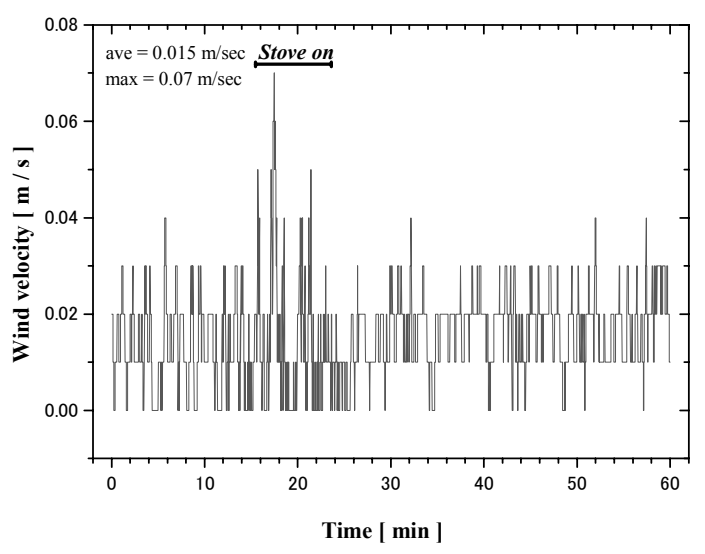

(a) 室内の風量変化

(a) Wind velocity characteristic.

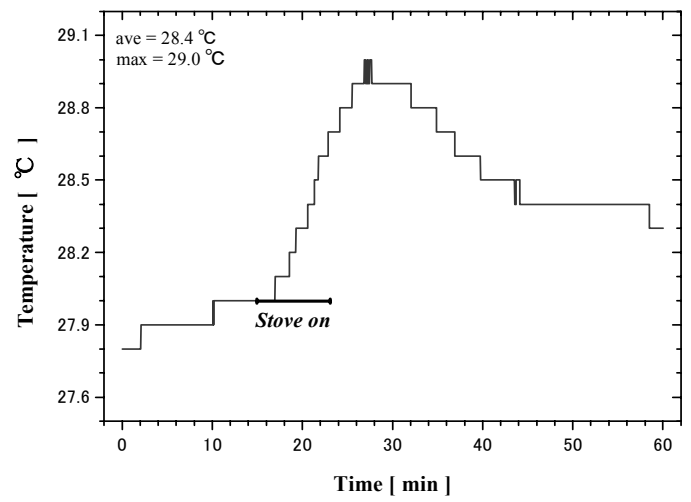

(b) 室内の温度変化

(b) Temperature characteristic.

図 3 電気コンロ通電時の室内風量変化と温度変化 Fig. 3. Wind velocity and temperature characteristics in the experimental room under electric stove $\mathrm{ON}$.
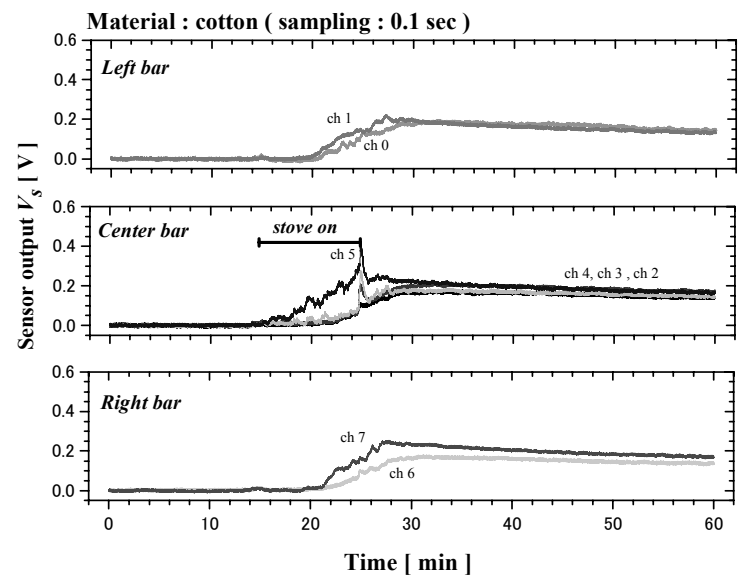

図 4 綿布燻焼時のセンサ特性

Fig. 4. Sensor characteristics for smoldering fire of cotton cloth.

いる。さらに, Fig. 4 の特徵が増幅されて表れている。Center bar の ch 5 のセンサ特性が顕著である。Fig. 5 の特徵を明確 に示すために, Fig. 5 の差分特性を求めた。それを Fig. 6 に

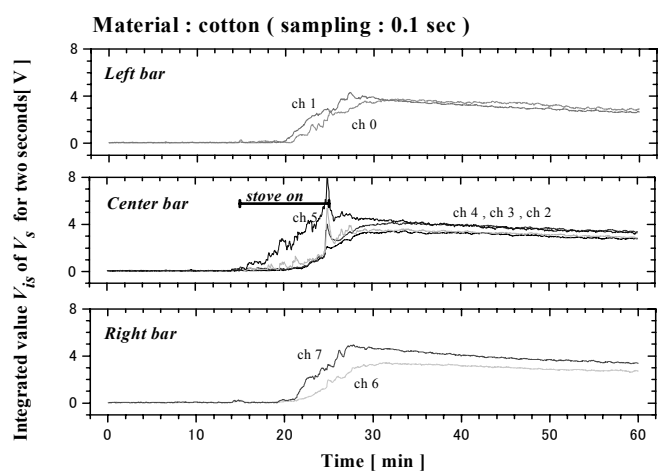

図 5 綿布燻焼時のセンサ出力の 2 秒間積分值特性

Fig. 5. Integrated value characteristics of sensor output for two seconds.

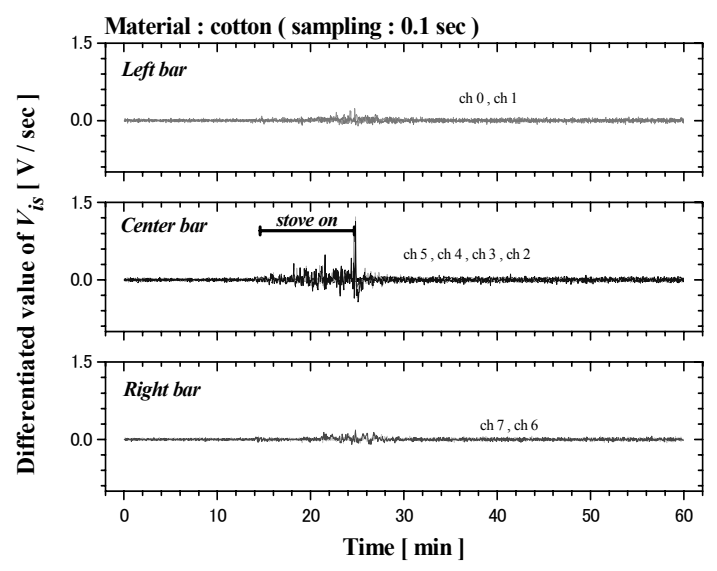

図 6 綿布燻焼時の積分值の差分特性

Fig. 6. Differential characteristics of integrated value for smoldering fire of cotton cloth.

示す。このとき差分特性が大きく変化しているのは Center bar に設置された ch 4,5 である。電気コンロが ONになる とともに ch 4 と 5 の特性が変動し 3 分後に大きく変動して いることがわかる。すなわち，火災源に近い支柱のセンサ が早く反応していることがわかる。

Fig. 6 の特性に闇值 $V_{t h}(0.2[\mathrm{~V} / \mathrm{sec}])$ を設け, その值を 超えた最初の時刻を計測した。それを Fig. 7 に示す。図は 3 回実験を行った結果の平均值をプロットしてある。電気コ ンロのスイッチを入れてから 4 分程度で ch 5, 4 のセンサが

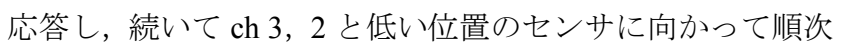
検知していくことがわかる, 縦軸は閾值 $\left(V_{t h}\right)$ を超えたときの 時刻である。ch 5 のセンサは 3 分 30 秒程度で閾值 $\left(V_{t h}\right)$ を超 えたことになる。ch 4 も比較的早く超えているが ch 3 と 2 は 8 分以上かかっている。Left bar と Right bar のセンサも 7 分以上かかっている。高い位置にあるセンサ程早く応答し ている。

他の 3 物質についても同様の解析を行った。Fig. 8 に木く ず, Fig. 9 に壁紙, Fig. 10 にカーテン布の結果を示す。いず 


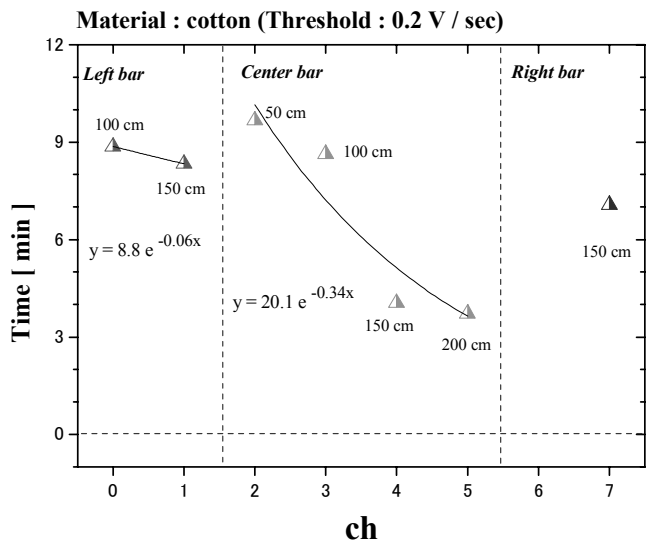

図 7 綿布燻焼時の差分特性における閾值を超えた 平均時間

Fig. 7. Average time at which $V_{\text {is }}$ exceed the threshold value for smoldering fire of cotton.

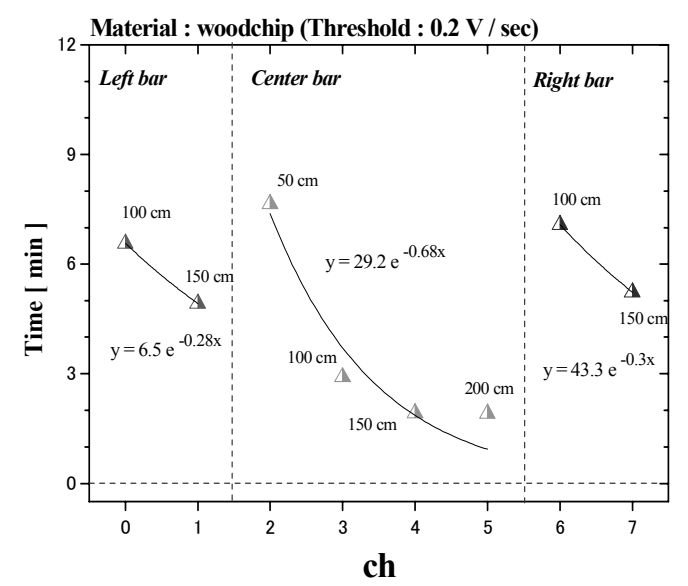

図 8 木くず煄焼時の差分特性における閾值を超えた 平均時間

Fig. 8. Average time at which $V_{i s}$ exceed the threshold value for smoldering fire of woodchip.

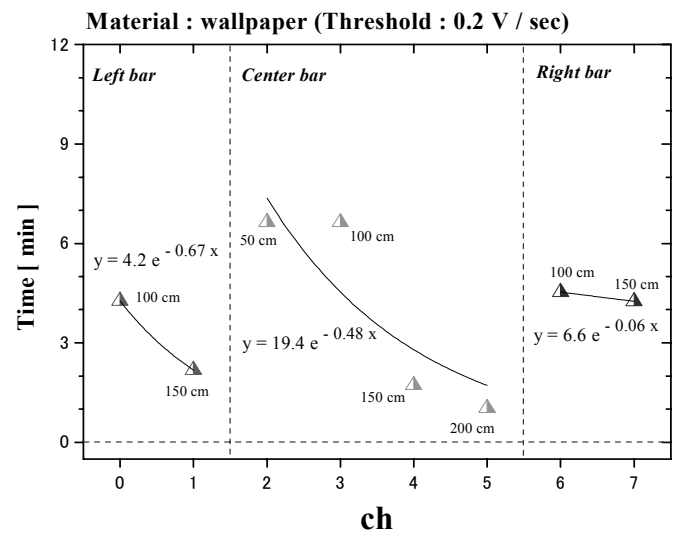

図 9 壁紙燻焼時の差分特性における閾值を超えた 平均時間

Fig. 9. Average time at which $V_{i s}$ exceed the threshold value for smoldering fire of wallpaper.

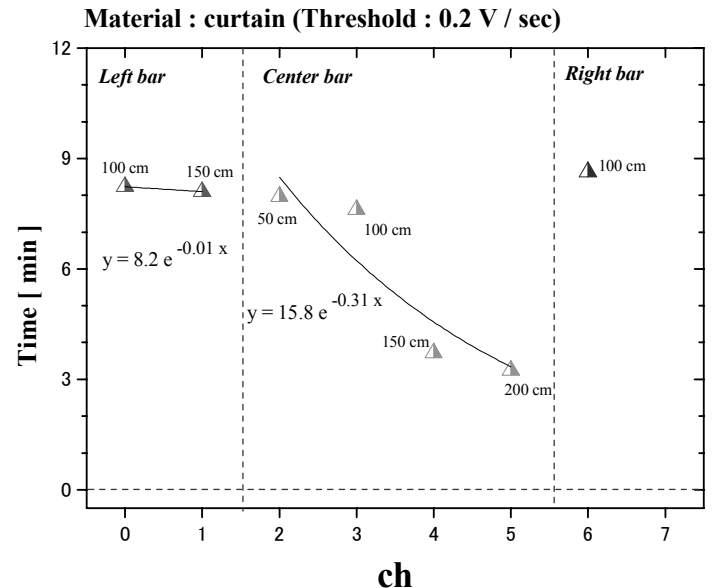

図 10 カーテン燻焼時の差分特性における閾值を超えた 平均時間

Fig. 10. Average time at which $V_{i s}$ exceed the threshold value for smoldering fire of curtain.

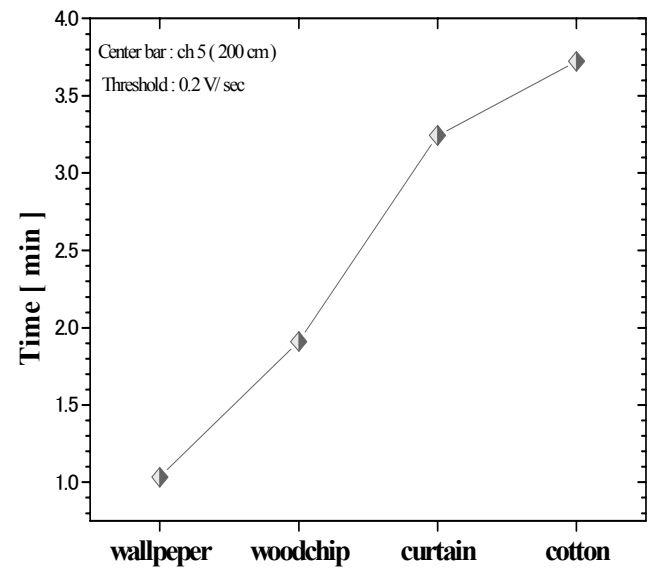

図 11 実験に使用した 4 つの試料に対して ch 5 が 閾值を超えた時間

Fig. 11. Time in which $V_{i s}$ of ch 5 sensor exceeded the $V_{t h}$ for the four materials.

れの試料も一番高い位置のセンサから応答し, 4 分以内で検 知していることがわかる。以上の事柄により，ガスセンサ を用いて燻焼火災を検知する場合は高い位置にセンサを配 置する必要があるといえる。実験に使用した 4 つの試料の 中で最も早く覚知できたのは壁紙であった。続いて木くず, カーテン布, 綿布となっている。カーテン布と綿布の覚知 に 3 分以上要する。各試料の実験で Center bar に取り付けて ある ch $5(200 \mathrm{~cm})$ が閾值 $\left(V_{t h}\right)$ を超えたときの時間を Fig. 11 に 示す。壁紙は最も早く検知される。壁紙や木くずは燻焼火 災になるとガス状物質が出やすいといえる。壁紙の多くは 原料に合成樹脂が使われており，木くずが燃えるとセルロ 一ス等が多量に発生する。

〈3.3〉 センサ出力特性の主成分分析結果 実験は各 試料に対して 3 回ずつ行った。各実験において間值を超え た時間を求めた。その結果に対して主成分分析を行い燻焼 


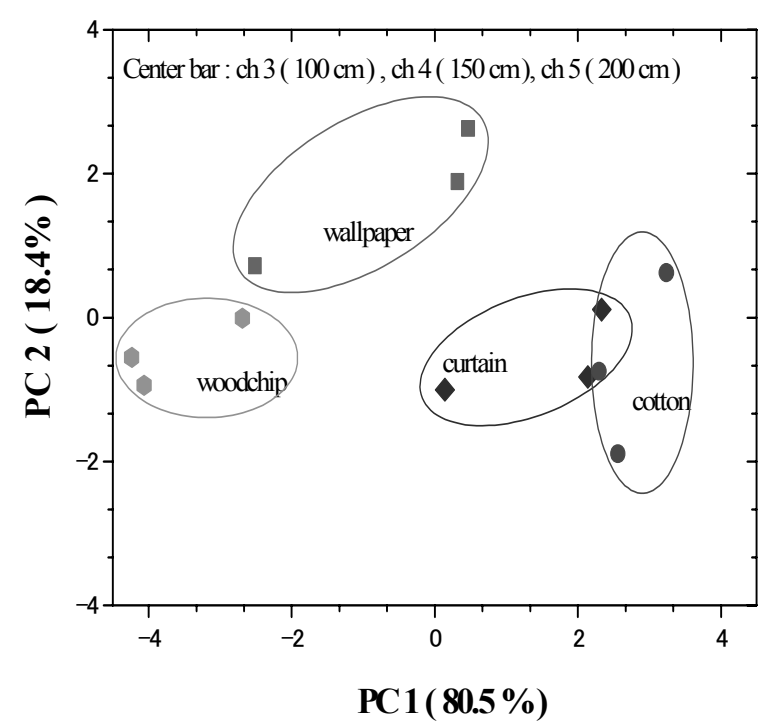

図 123 センサを用いた主成分分析結果

Fig. 12. Principal component analysis results of ch 3, 4 and 5 sensors for four types of smoldering fire.

試料の同定を試みた。その結果を Fig. 12 に示す。図では発 火源から一番近い Center bar に取り付けた ch 3，4，5 のセン サを用いて主成分分析を行った。図は横軸に第 1 主成分, 縦軸に第 2 主成分が示されている。各主成分を表す式を以 下に示す。 $x_{1}, x_{2}, x_{3}$ は ch $3 ， 4 ， 5$ のセンサが $V_{t h}$ を超えた 時間である。第 1 主成分 $\left(z_{1}\right)$ が $80.5 \%$ の情報量を有している ことになる。

$$
\begin{aligned}
& z_{1}=0.91 x_{1}+0.30 x_{2}+0.27 x_{3} \\
& z_{2}=0.41 x_{1}-0.61 x_{2}-0.67 x_{3} \\
& z_{3}=-0.04 x_{1}+0.72 x_{2}-0.68 x_{3} .
\end{aligned}
$$

各試料に対して 3 つのプロットが示されており各々クラ スターを形成している。特に，木くずと壁紙の判別は容易 である。すなわち，第 1 主成分ではニオイの強さを示して いると考えられる。数值が小さくなる程, ニオイが強い。 また，第 2 主成分はガス成分の上部に向かって拡散する速 さを示していると考えられる。数值が大きい程拡散するス ピードが早い。すなわち，壁紙に使用されている合成樹脂 が速く燻焼することにより発生するガス成分は高い位置に 向かって上昇する, ch 5 のセンサは早く応答するが ch 3,4 のセンサの応答は木くずよりも遅くなる。この結果より, 火災源種の同定を行うには高さ方向に 3 つのセンサ特性を 用いる必要がある。

\section{4. まとめ}

消防法の改正により，一般新築住宅への火炎報知機の設 置が義務付けられた。また，既存住宅でも火災報知機の設 置により保険料の割引サービス実施や市町村が定めた期日 までの火災報知機の設置が義務付けられている。このため, 高性能で信頼性の高い火災報知機の開発は急務である。火 災報知機は光, 温度, ガス, 煙を検知する様々なタイプが あり室内環境に合わせた選択が必要である。さらに，様々
な火災源種に対応するものでなければならない。早期検知 を行うには, 複数センサからの特性を常時モニタリングし, 加工を行い素早い警報と情報伝達を行えるシステムが必要 である。

本研究では, 酸化スズ系ガスセンサを用いた燻焼火災検 知について検討を行った。実験の結果, 当該センサは火災 発生から 4 分以内での検知が可能である。高齢者などの逃 げ遅れ対策に十分対応できるものと考えられる。また, 火 災源から近い複数のセンサ特性を用いて, 主成分分析を行 うことにより，一部の火災源種の同定も可能である。実験 においては, 同型複数ガスセンサを配置し, その出力特性 から差分特性を求めることにより燻焼火災を認知する手法 について調べた。他のセンサでは難しい 4 分以内での検知 が可能となった。また, それらセンサの主成分分析を行う ことにより，いくらか火災源種も同定できることが明らか となった。今後は異なった型のガスセンサを組み合わせる ことで早期火災発見とその種類を同定することを試みる。

\section{謝 辞}

本研究の一部は総務省消防庁消防防災科学技術研究推進 制度により行われたものである。ここに記し深く感謝申し 上げる。

(平成 18 年 9 月 13 日受付, 平成 19 年 2 月 22 日再受付)

\section{文献}

(1) 消防庁編: 「消防白書」,ぎょうせい (平成 17 年)

(2) T. Oyabu : "A simple type of fire and gas leak prevention system using tin oxide gas sensors", SENSORS AND ACTUATORS B Chemical, Vol.5, pp.227-229 (1991)

(3) T. Oyabu : "An algorithm for evaluating disasters by fuzzy reasoning", SENSORS AND ACTUATORS B Chemical, Vol.10, No.2, pp.143-148(1993)

(4) 大娄多可志・木村春彦:「プロダクションシステムを用いた家庭内災 害の同定」，計測自動制御学会論文誌，Vol.30, No.9, pp.1077-1083 (1994)

（5）田代哲朗・竹井義法・笠原 浩・岩崎幸代・南戸秀仁：「防災用ガス センサアレイの開発と火災探知ロボットーの応用」, 電気学会・ケミ カルセンサ研究会, CHS-04-28, pp.5-10 (2004 年 12 月 3 日)

(6) 東野翼 - 沢田史子 - 大薮多可志・新保達也・石榑大介・竹井義法 . 南戸秀仁・都甲 潔:「タバコ燻焼火災に対するガスセンサ特性」, 電 気学会ケミカルセンサ研究会, CHS-06-5, pp.17-21 (2006-5)

( 7 ) A. Sawada, T. Shimbo, T. Oyabu, Y. Takei, H. Nanto, and K. Toko : "Gas sensor characteristics for smoldering fire caused by a cigarette smoke", The 11th International Meeting on Chemical Sensors, TP46 (July 16-19, 2006, Brescia, Italy)

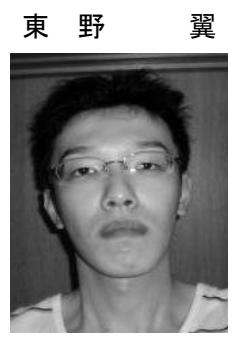

（学生員） 1983 年 8 月 6 日生。2006 年 3 月金 沢星稜大学経済学部卒業。同年, 金沢星稜大学 大学院地域経済システム研究科入学。現在, ガ スセンサを用いた火災検知システム開発に従 事。また，複数のセンサを用いた室内環境認知 に興味を持つ。 


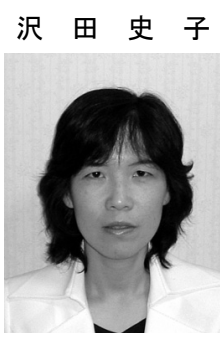

（正員） 2005 年 3 月北陸先端科学技術大学院 大学知識科学研究科博士後期課程修了。同年金 沢星稜大学非常勤講師, 現在に至る。ガス・ 二 オイセンサを用いたセンシングシステム, 観光 情報学などの研究に従事. 博士 (知識科学)。 計測自動制御学会, 日本設備管理学会, 観光情 報学会各会員。

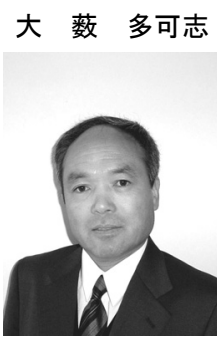

（正員） 1973 年工学院大学工学研究科修士課 程修了。75 年早稲田大学第二文学部英文科卒 業。 80 年金沢女子短期大学講師, 助教授, 教授 を経て 94 年富山国際大学人文学部教授。9 8 年 金沢星稜大学経済学部教授。現在，植物の環境 浄化能力の評価に関する研究に従事（工学博 士)。電子情報通信学会, 計測自動制御学会, 電気化学会, 日本設備管理学会各会員。

（正員） 1996 年福岡大学工学部電気工学科卒

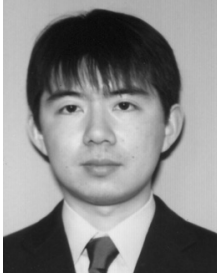

業。2001 年九州大学大学院システム情報科学研 究科博士後期課程単位取得後退学。同年同大学 大学院システム情報科学研究院助手。2002 年金 沢工業大学工学部研究員を経て, 2004 年同大学 工学部ロボティクス学科講師，現在に至る。博 士 (工学)。システム同定, 匂い及び味センサ に関する研究に従事。計測自動制御学会会員。

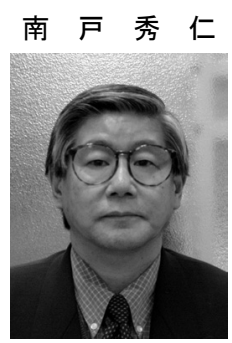

(正員) 1980 年大阪大学大学院工学研究科原 子力学専攻博士課程修了 (工学博士)。金沢工 業大学工学部助教授を経て, 1998 年同教授, 現 在に至る。現在, 金沢工業大学高材センター所 長, におい及び放射線センサシステムの研究開 発に従事, 1988 年から 1989 年マサチューセッ ツ工科大学エレクトロニクス研究所客員研究 員。

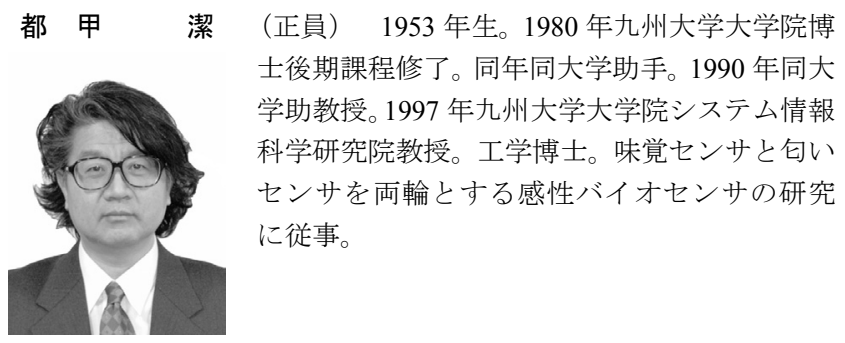

